\title{
Production, purification and characterization of a novel thermotolerant endoglucanase (CMCase) from Bacillus strain isolated from cow dung
}

\author{
Sangrila Sadhu', Pradipta Saha², Sukanta K Sen ${ }^{3}$, Shanmugam Mayilraj ${ }^{4}$ and Tushar Kanti Maiti*
}

\begin{abstract}
In an attempt to screen out cellulase producing bacteria from herbivorous animal fecal matter it was possible to isolate a potent bacterium from cow dung. The bacterium was identified as Bacillus sp. using $16 \mathrm{~S}$ rDNA based molecular phylogenetic approach. The effect of different agricultural wastes, paper wastes and carboxymethyl cellulose on endoglucanase production was tested and was found to produce maximally at $8 \%$ carboxymethyl cellulose. The endoglucanase was precipitated by ammonium sulfate saturation and purified by DEAE- Sepharose column. The purification was achieved 8.5 fold from the crude extract with a yield of $68.1 \%$. The molecular weight of the protein was determined to be $97 \mathrm{kDa}$ by SDS-PAGE. The enzymatic activity was moderately reduced by detergents (SDS, Tween-80), metal ions $\left(\mathrm{MnCl}_{2}, \mathrm{ZnCl}_{2}\right)$ and EDTA. The endoglucanase was stable between pH 5.0 9.0 and temperature between $20-70^{\circ} \mathrm{C}$ with optimal activity at $\mathrm{pH} 7.0$ and temperature $50^{\circ} \mathrm{C}$. The apparent $\mathrm{Km}$ value of the enzyme for the substrate carboxymethyl cellulose was recorded to be $0.25 \mathrm{mg} / \mathrm{ml}$. The endoglucanase was stable in the presence of commercial detergents such as Ariel, Surf Excel and Tide, indicated might be of potential applications in detergent industry. The enzyme from this strain could also be applied in bioconversion of lignocellulosic biomass into fermentable sugars.
\end{abstract}

Keywords: Endoglucanase (CMCase), Bacillus sp, Thermostable

\section{Background}

A promising approach relies on the production of bioethanol from the abundant and renewable lignocellulosic biomass (Hahn-Hägerdal et al. 2006). Cellulose, the most common natural renewable biopolymer, is commonly degraded by the hydrolytic action of a multicomponent enzyme system - the cellulase and represents the key step for biomass conversion. The enzymatic hydrolysis requires synergistic action of cellobiohydrolase or exoglucanase (E.C.3.2.1.91), endoglucanase or carboxymethylcellulase (E.C. 3.2.1.4) and cellobiase or $\beta$-glucosidase (E.C.3.2.1.21).

Applications of this enzyme such as the production of animal feed, formulation of detergents, juice clarification, paper industry and wine production. Cellulases contribute to $8 \%$ of the worldwide industrial enzyme demands and the demand is expected to increase by

\footnotetext{
* Correspondence: tkmbu@yahoo.co.in

'Microbiology Laboratory, Department of Botany, Burdwan University, Burdwan 713104WB, India

Full list of author information is available at the end of the article
}

100\% within 2014 (Costa et al. 2008). For these processes thermophilic and or alkalophillic or acidophilic microorganisms as sources of thermostable and wide range of $\mathrm{pH}$ stable enzymes are needed, because of their higher stability and activity over a wider range of temperatures and pH (Bakare et al. 2005; Viikari et al. 2007).

However, bacteria may also serve as a novel source cellulases due to their higher growth rate, more complex glycoside hydrolases providing synergy with higher potency because of organismal diversity of extreme niches. The latter feature provides them capabilities to produce cellulases that can withstand extreme conditions (Miranda et al. 2009) like thermostability, acid and alkalistability, which makes them successful candidate for industrial applications.

Many workers have purified and characterized cellulases isolated from different bacteria viz. Thermomonospora sp. (George et al. 2001), Cellulomonas sp. YJ5 (Yin et al. 2010), Melanocarpus sp. MTCC 3922 (Kaur et al. 2007), Pseudomonas fluorescens (Bakare et al. 2005), Pyrococcus 
horikoshi (Kang et al. 2007), Bacillus sp (Acharya and Chaudhury 2011; Ashabil et al. 2011, Bajaj et al. 2009, Bischoff et al. 2006, Kim et al. 2005; Singh et al. 2004). The present manuscript deals with the production, purification and characterization of a thermostable endoglucanase from Bacillus sp. C1 (MTCC10046), isolated from cow dung. The property of the purified enzyme was studied to understand its potential for biotechnological application.

\section{Results and discussion}

\section{Isolation and identification of cellulolytic bacteria}

Out of 20 bacterial isolates from cow dung the isolate C1 was selected as potent cellulose hydrolyser using Omeliansky's agar medium forming clear zone around growth and by cellulase assay with cell free culture filtrate. Cow dung was selected as a source for obtaining desirable cellulase producing organisms, because it is a rich source of diverse group of cellulolytic microorganisms owing to diet of the ruminants which consists of high amounts of cellulosic matter. The isolate was characterized through cultural, morphological, physiological and biochemical studies (data not shown except carbon sources utilization pattern by BIOLOG method in Table 1). The strain was deposited in Microbial Type Culture Collection \& Gene Bank (MTCC), Chandigarh, India and its accession number is MTCC 10046. The nucleotide accession number of $16 \mathrm{~S}$ rDNA is HM171927 obtained from NCBI. Among well established species of the genus Bacillus, the strain $\mathrm{C} 1$ showed closest sequence identity (99.04\%) with Bacillus circulans ATCC $24^{\mathrm{T}}$ followed by Bacillus nealsonii DSM $15077^{\mathrm{T}}$ (Figure 1). Sequence similarity with type strains of other Bacillus Spp. was less than $98 \%$. In the absence of overall genome relatedness, chemotaxonomic data, the strain $\mathrm{C} 1$ is identified as Bacillus sp.

\section{Effect of different carbon sources for endoglucanase production}

Cellulase production was found to be dependent upon the nature of the carbon source used in culture media. The choice of a cheapest and appropriate substrate is of great importance for the successful production of enzymes. It was found that the strain could grow in all the substrates used but CMC promoted yield maximally when compared to agricultural waste or paper waste (Table 2). It is assumed that this is due to the less complexity and hence easy assimilation of it by the isolated microbe (Wood and Bhat 1988). Among the agricultural waste groundnut, paddy straw, banana pseudostem, sugarcane baggasse, coconut fiber were shown much low in enzymes production but orange scale showed comparatively better for enzymes production. However, newspaper waste showed significant production of enzymes. Though carboxymethyl cellulose exhibited extensive role to enzyme yield and production, the agricultural wastes (orange scale, sugarcane baggasse) may also be utilized for enzyme production as cheaper carbon source. The CMC was further tested at different concentrations for cellulase production by the isolate $\mathrm{C} 1$ strain and found 8\% CMC was optimum for cellulase production maximally (Figure 2).

\section{Extraction and partial purification of extracellular enzymes}

Extraction of the crude enzyme was carried out by ammonium sulphate precipitation after standardization and maximum activity was recorded at $40-80 \%$ saturation. The precipitate was centrifuged, dissolved in acetate buffer $(0.02 \mathrm{M}, \mathrm{pH} 5.2)$ and dialyzed. It was found that of $40-60 \%$ ammonium sulphate saturation are common for purification of bacterial cellulase (Sudan and Bajaj 2007). However, cellulase of Pseudomonas fluorescens was purified at $90 \%$ ammonium sulfate saturation (Bakare et al. 2005) while in Thermomonospora, the cellulase was precipitated by using fractional ammonium sulfate $30-88 \%$ (George et al. 2001).

\section{DEAE-Sepharose chromatography}

Dialyzed enzyme solution from ammonium sulfate precipitation steps was subjected to ion exchange chromatography on DEAE-Sepharose column. The dialyzed proteins of crude enzyme extract were separated in different eluted fractions. All the fractions are assayed for endoglucanase activity by DNS method and it was found that Fraction (E5) shown maximum endoglucanase activity $(68.1 \mathrm{U} / \mathrm{mg})$. A brief summary of the purification steps was presented in Table 3. The specific activity of enzyme was sequentially increased at each purification step and final increment was more than 8.0 fold. Cellulase was purified 9.06 folds from Bacillus strain M-9 with DEAE-cellulose chromatography (Bajaj et al. 2009) and in Cellulomonas sp. YJ5, the enzyme was purified 17.5 fold with sephacryl S-100 chromatography (Yin et al. 2010).

\section{SDS-PAGE and molecular weight determination}

The endoglucanase activity was confirmed by Congo red assay through agarose slab gel method (Figure 3). Cellulase fractions from DEAE-Sepharose column with highest activity were pooled, subjected to SDS-PAGE and the molecular weight (MW) was determined and it was $97 \mathrm{kDa}$ (Figure 4). The molecular weight of endoglucanase varies with different bacteria. The MW was similar with some other high MW endoglucanases like alkalophilic Bacillus sp. HSH-810 where it is $80 \mathrm{kDa}$ (Kim et al. 2005) and Sinorhizobium fredii sp. strain CCRC 15769 it is $94.0 \mathrm{kDa}$ (Chen et al. 2004). In Pseudomonas fluorescens it is $36 \mathrm{kDa}$ (Bakare et al. 2005) while in Bacillus strains it is $54 \mathrm{kDa}$ (Lee et al. 2008, Bajaj et al. 2009). But in 
Table 1 Oxidation of substrates using Biolog GP2 microplates

\begin{tabular}{|c|c|c|c|c|c|}
\hline $\begin{array}{l}\text { Oxidation of substrate using } \\
\text { Biolog GP2 microplates }\end{array}$ & $\mathrm{C} 1$ & $\begin{array}{l}\text { Oxidation of substrate using } \\
\text { Biolog GP2 microplates }\end{array}$ & $\mathrm{C} 1$ & $\begin{array}{l}\text { Oxidation of substrate using } \\
\text { Biolog GP2 microplates }\end{array}$ & C1 \\
\hline a-cyclodextrin & + & maltotriose & + & acetic acid & - \\
\hline$\beta$ cyclodextrin & + & D-mannitol & + & a- hydroxybutyric acid & - \\
\hline Dextrin & + & D-mannose & + & $\beta$ - hydroxybutyric acid & - \\
\hline glycogen & + & D-melezitose & - & Y-hydroxybutyric acid & - \\
\hline Inulin & - & D-Melibiose & - & p-hydroxyphenylacetic acid & - \\
\hline mannan & - & $\beta$-methyl-D-galactoside & - & a-ketoglutaric acid & - \\
\hline tween-40 & - & a -methyl-D-galactoside & - & a -ketovaleric acid & - \\
\hline tween-80 & - & 3-methyl-D- glucose & - & Lactamide & - \\
\hline N-acetyl-D-Glucosamine & + & a -methyl-D-glucoside & - & D-lactic acid Methyl Ester & - \\
\hline N-Acetyl $\beta$-D-mannosamine & - & $\beta$-methyl-D-glucoside & + & L-lactic acid & - \\
\hline amygdain & - & a -methyl-D-mannoside & - & D-Malic Acid & - \\
\hline L-arabinose & - & palatinose & - & L-Malic Acid & + \\
\hline D-arabitol & - & D-psicose & - & Pyruvic acid methyl ester & - \\
\hline Arbutin & + & D-raffinose & - & Succinic Acid mono methyl ester & - \\
\hline D-cellobiose & + & L-rhamnose & - & Propionic acid & - \\
\hline D-cellobiose & + & D-ribose & - & pyruvic acid & - \\
\hline D-fructose & + & salicin & + & Succinamic Acid & - \\
\hline L-fucose & - & sedoheptulosan & - & Succinic Acid & - \\
\hline D-galacturonic acid & - & D-sorbitol & + & N-Acetyle L Glutamic Acid & - \\
\hline D-galactose & - & stachyose & - & L-Alaninamide & - \\
\hline gentiobiose & - & sucrose & + & D-Alanine & - \\
\hline D-gluconic acid & - & D-tagatose & - & L-Alanine & - \\
\hline a-D-glucose & + & D-trehalose & + & L-Alanyl-Glycine & - \\
\hline m-inositol & - & Turanose & - & L-Asparagine & - \\
\hline a -D- lactose & - & Xylitol & - & L-Glutamic Acid & - \\
\hline lactulose & + & D-xylose & + & Glycyl-L-Glutamic Acid & - \\
\hline maltose & + & L-Pyroglutamic Acid & - & uridine & - \\
\hline L-Serine & - & adenosine & - & Adenosine 5'-monophosphate & - \\
\hline Putrescine & - & 2-deoxy adenosine & - & Thymidine-5'-Monophosphate & - \\
\hline 2-3 butenediol & - & inosine & - & Uridine 5'-monophosphate & - \\
\hline glycerol & - & thymidine & - & D-Fructose-6-Phosphate & - \\
\hline a-D-Glucose-1-Phosphate & - & D-Glucose-6-Phosphate & - & D-L- a-glycerol phosphate & - \\
\hline
\end{tabular}

Thermomonospora and Cellulomonas sp. YJ5 it is $38 \mathrm{kDa}$ (George et al. 2001), and $43.7 \mathrm{kDa}$ (Yin et al. 2010) respectively.

\section{Determination of $K_{m}$ value of purified endoglucanase}

$K_{m}$ value of purified extracellular cellulase was determined by Lineweaver Burk double reciprocal plot at varying substrate $(\mathrm{CMC})$ concentration and found as $0.25 \mathrm{mg} / \mathrm{ml}$. The $\mathrm{V}_{\max }$ and $\mathrm{k}_{\text {Cat }}$ were found $20 \mu \mathrm{mole} \cdot \mathrm{ml}^{-1} \cdot \mathrm{min}^{-1}$ and $0.55 \mathrm{~s}^{-1}$ respectively (Figure 5 ). The activity of endoglucanase was greatly influenced by the substrate concentration in this organism. The $K_{m}$ value of cellulase was found $3.6 \mathrm{mg} / \mathrm{ml}$ in Pseudomonas fluorescens (Bakare et al. 2005), as $4.97 \mathrm{mg} / \mathrm{ml}$ in Actinobacteria anitratus and $7.90 \mathrm{mg} / \mathrm{ml}$ in Branhamella sp (Ekperigin 2007). It is difficult to explain difference of $\mathrm{K}_{\mathrm{m}}$ values of insoluble substrate like cellulose, however, it may be due to the isolates are of different source. The $K_{m}$ value denotes the amount of substrate needed to achieve half the maximal initial reaction velocity (Tong et al. 1980) and is a measure of the apparent affinity of an enzyme for its substrate. 


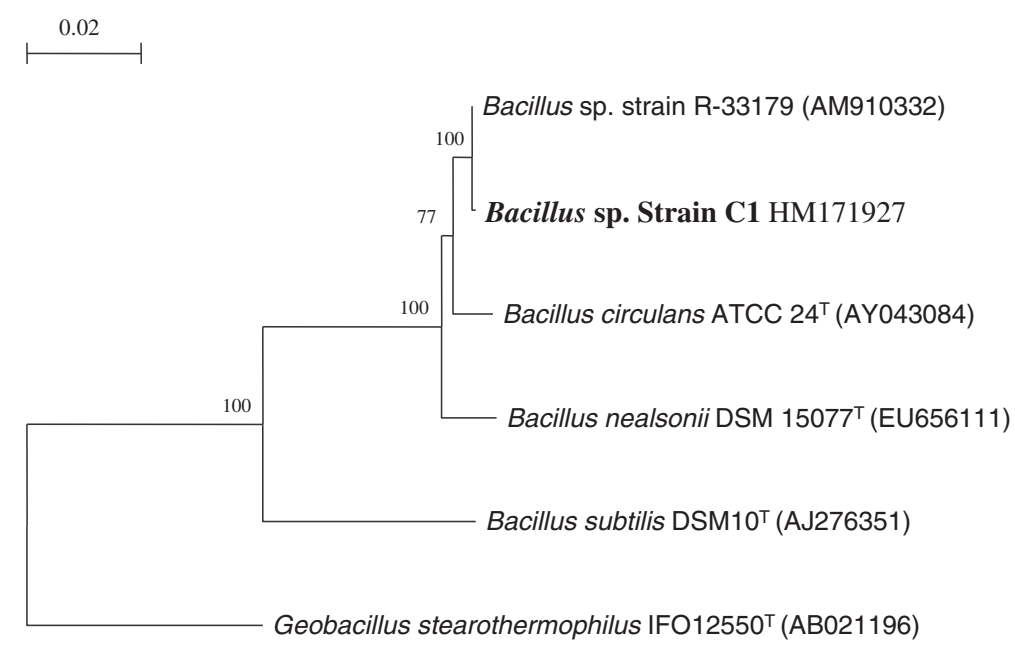

Figure 1 Phylogenetic tree based on neighbour-Joining method, showing the relationship between strain C1 with other related taxa. Bootstrap values of 100 replications are shown at the branch. The tree was generated using TREECON (Van de Peer \& Wachter, 1997) and Jukes \& Cantor (1969) correction. Sequence from Geobacillus stearothermophilus strain DSM10 ${ }^{\top}$ was taken as out group Bar. 0.02 base substitutions per site.

Effect of various chemicals on endoglucanase activity The effects of various metal ions did not show enhancement of enzyme activity of this strain (Figure 6). But, one unifying finding was that these additives inhibited enzyme activity to a certain level only. This indicated robust nature of the enzyme desirable for industrial application. Such type of enzyme inhibition was also noted in Bacillus sp (Bajaj et al. 2009) and in Pseudomonas fluorescens (Bakare et al. 2005).

\section{Effect of temperature on endoglucanase activity}

Purified enzyme preparation was recorded to show activity over a broad range of temperature $\left(20^{\circ}-70^{\circ} \mathrm{C}\right)$ with the optimal activity at $50^{\circ} \mathrm{C}$ and declined thereafter (Figure 7A). Thermo-stability range of the enzyme showed that it was thoroughly stable at $50^{\circ} \mathrm{C}$. However, activity of this enzyme gradually declined with increase of temperature from $60-70^{\circ} \mathrm{C}$ (Figure 7B). Nevertheless, sufficient activity of the enzyme (more than $75-80 \%$ ) was present at $60-70^{\circ} \mathrm{C}$ for $1-2 \mathrm{~h}$. This kind of stability of enzyme might comply with the industrial process requirements it possessed prolonged stability under high temperature. The optimum temperature of cellulase was lower than some of other Bacillus strains as $60^{\circ} \mathrm{C}$ in M-9 (Bajaj et al. 2009), $65^{\circ} \mathrm{C}$ in $\mathrm{CH} 43,70^{\circ} \mathrm{C}$ in RH68 (Mawadza et al. 2000), and was similar to those from other Bacillus strains $0-50^{\circ} \mathrm{C}$ (Mawadza et al. 2000), in Bacillus amyoliquefaciens DL3 (Lee et al. 2008) and in Thermomonospora (George et al. 2001). But the endoglucanase of Bacillus licheniformis $\mathrm{C} 108$ was highly stable up to $100^{\circ} \mathrm{C}$ (Ashabil et al. 2011) and shown better stability than that of other

Table 2 Effect of different carbon sources $1 \%(\mathrm{~W} / \mathrm{V})$ on cellulase production by Bacillus sp after $8 \mathrm{~d}$ of incubation at $37^{\circ} \mathrm{C}$

\begin{tabular}{|c|c|c|c|c|}
\hline $\begin{array}{l}\text { Agricultural waste } \\
(1 \% \mathrm{~W} / \mathrm{V})\end{array}$ & $\begin{array}{l}\text { CMCase } \\
\text { (U/mg protein) }\end{array}$ & $\begin{array}{l}\text { Avicelase } \\
\text { (U/mg protein) }\end{array}$ & $\begin{array}{l}\text { FPase } \\
\text { (U/mg protein) }\end{array}$ & $\begin{array}{l}\text { B-glucosidase } \\
\text { (U/mg protein) }\end{array}$ \\
\hline Paddy straw & $0.111 \pm 0.005$ & $0.197 \pm 0.008$ & $0.133 \pm 0.005$ & $0.111 \pm 0.005$ \\
\hline Sugarcane baggasse & $0.177 \pm 0.0152$ & $0.213 \pm 0.010$ & $0.170 \pm 0.0152$ & $0.119 \pm 0.005$ \\
\hline Banana seudo stem & $0.130 \pm 0.005$ & $0.135 \pm 0.0152$ & $0.150 \pm 0.0152$ & $0.135 \pm 0.0152$ \\
\hline Groundnut scale & $0.07 \pm 0.008$ & $0.07 \pm 0.008$ & $0.08 \pm 0.0115$ & $0.03 \pm 0.0057$ \\
\hline Coconut fruit fibre & $0.153 \pm 0.0152$ & $0.153 \pm 0.0152$ & $0.186 \pm 0.0152$ & $0.108 \pm 0.0115$ \\
\hline Orange scale & $0.54 \pm 1.528$ & $0.59 \pm 1.527$ & $0.62 \pm 0.0115$ & $0.60 \pm 0.015$ \\
\hline Whatman filter paper & $0.52 \pm 0.011$ & $0.50 \pm 0.011$ & $0.51 \pm 0.011$ & $0.52 \pm 0.011$ \\
\hline Newspaper & $0.65 \pm 0.577$ & $0.60 \pm 0.015$ & $0.70 \pm 0.0185$ & $0.72 \pm 0.010$ \\
\hline Printing paper & $0.50 \pm 0.011$ & $0.52 \pm 0.011$ & $0.48 \pm 1.154$ & $0.45 \pm 0.010$ \\
\hline Foolscape paper & $0.45 \pm 0.010$ & $0.42 \pm 0.0152$ & $0.50 \pm 0.011$ & $0.42 \pm 0.0152$ \\
\hline CMC & $0.73 \pm 0.02$ & $0.77 \pm 1.201$ & $0.84 \pm 0.015$ & $0.93 \pm 1.527$ \\
\hline Avicel & $0.26 \pm 0.0152$ & $0.45 \pm 0.010$ & $0.32 \pm 1.527$ & $0.26 \pm 0.0152$ \\
\hline
\end{tabular}

The results of one-way factorial ANOVA reveals the amount of enzymes synthesized are in different C-sources varied significantly. $\mathrm{F}$ value is significant at $\mathrm{P}<0.01$ level. 


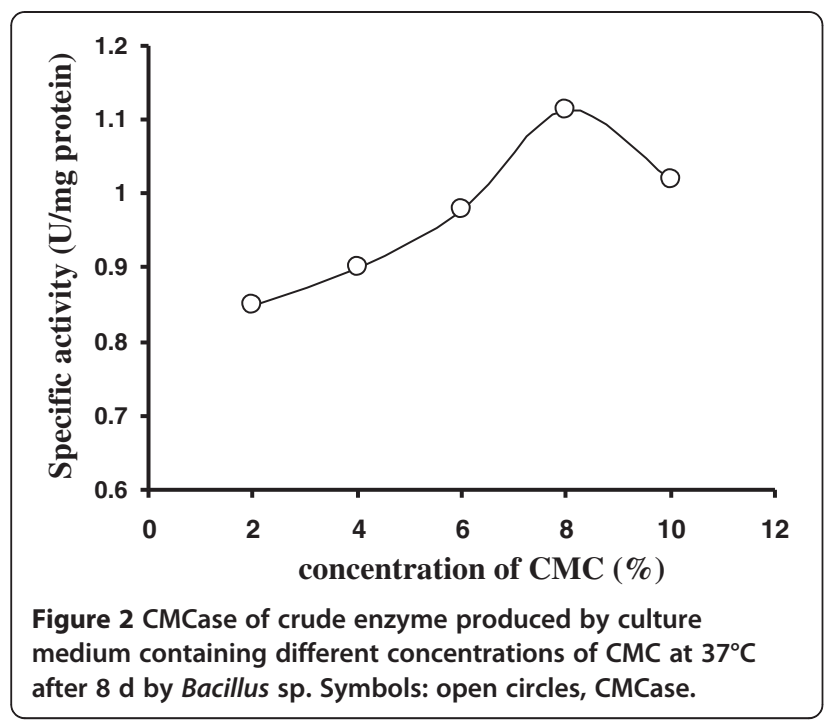

Bacillus sp (Kim et al. 2005). The cellulase of Brevibacillus sp strain JXL had high thermotolerance by retaining more than $50 \%$ activity at $100^{\circ} \mathrm{C}$ after $1 \mathrm{hr}$ (Liang et al. 2009) but alkalotolerant Nocardiopsis sp. KNU retaining 55-70\% activity at $80^{\circ} \mathrm{C}$ in pH 5.0 (Saratale and $\mathrm{Oh} 2011$ ).

\section{Effect of $\mathrm{pH}$ on endoglucanase activity}

The enzyme hydrolyzed CMC in the $\mathrm{pH}$ range of 5.09.0, and exhibited highest activity at $\mathrm{pH} 7.0$ (Figure 7C). However, significantly high activity was also recorded on either side of this point which indicated that the enzyme has characteristically broad range of $\mathrm{pH}$ activity. The enzyme also had a broad range of $\mathrm{pH}(6.0-9.0)$ stability where it retained more than $80 \%$ activity for $1.0 \mathrm{hr}$, though maximum stability was found at $\mathrm{pH} 7.0$ (Figure 7D). Similar optimum enzyme activity was also found at $\mathrm{pH} 7.0$ in Pseudomonas fluorescence (Bakare et al. 2005), Bacillus amyoliquefaciens DL3 (Lee et al. 2008). But lower optimum pH (5.0) for enzyme activity with broad ranges of $\mathrm{pH}$ stability was found in Thermomonospora (George et al. 2001), and in Bacillus strain M-9 (Bajaj et al. 2009). Cellulase of Bacillus licheniformis was found to be more stable under acidic condition (Bischoff et al. 2006), however, it was optimally active at alkaline pH in Bacillus sp. HSH-910 (Kim et al. 2005) and in Bacillus sphaericus JS1 (Singh et al. 2004).
Stability of endoglucanase in the presence of commercial detergents

The endoglucanase of this Bacillus sp was also stable in different commercial detergents. The enzyme showed maximum stability in the presence of Ariel, having residual activity of $72 \%$ after incubation at $50^{\circ} \mathrm{C}$ for $1 \mathrm{hr}$ (Figure 8 ). The enzyme had $65 \%$ and $57 \%$ residual activities in the presence of Surf Excel and Tide respectively under similar condition (Figure 8). Data are in accordance with the results of Thermonospora sp (George et al. 2001). The alkalophilic Bacillus strain producing alkaline cellulase with $\mathrm{pH}$ optima in the range of $8.5-9.5$ having industrial application as laundry detergent additives (Shikata et al. 1990). Although this Bacillus sp. was capable of growing in neutral $\mathrm{pH}$ but it remain stable in broad range of $\mathrm{pH} \quad 6.0-9.0$ and in some detergents. Among the useful properties of the Bacillus cellulases per se are that many are active and stable over a wide range of $\mathrm{pH}$ and temperature (Lee et al. 2008).

\section{Conclusions}

It may be concluded that the organism Bacillus sp. MTCC 10046 has the potential to produce thermostable endoglucanase with broad range of $\mathrm{pH}$ and temperature stability which could have potential applications for wide range of industries. Industrial processes are generally carried out at elevated temperatures; therefore enzymes with high temperature optima and their stability are desired for industrial applications (Viikari et al. 2007). However, further investigation is needed in depth on optimization of cost effective substrate for bulk production of enzymes and molecular basis of thermostability.

\section{Methods}

Isolation and screening of cellulolytic bacteria

The bacterial strains were isolated from cow dung by serial dilution on Omeliansky's agar medium (Omeliansky 1902) $\left[\mathrm{g} / \mathrm{L}(\mathrm{W} / \mathrm{V}),\left(\mathrm{NH}_{4}\right)_{2} \mathrm{SO}_{4} 1.0 ; \mathrm{K}_{2} \mathrm{HPO}_{4} 1.0 ; \mathrm{MgSO}_{4} .7\right.$ $\mathrm{H}_{2} \mathrm{O}$ 0.5; $\mathrm{NaCl}$ traces; carboxymethyl cellulose (CMC) $1 \%, \mathrm{pH}$ 7.0]. Preliminary screening of cellulase producing isolates was carried out on CMC agar plates as mentioned by Teather and Wood (Teather and Wood 1982). Twenty bacterial isolates were selected out of which one (designated C1) with highest CMCase activity was finally selected. The strain $\mathrm{C} 1$ was identified as Bacillus sp. by full $16 \mathrm{~S}$ rDNA sequence homology and deposited to

Table 3 Summary of purification of endoglucanase from Bacillus sp MTCC 10046

\begin{tabular}{|c|c|c|c|c|c|c|c|}
\hline Sample & $\begin{array}{l}\text { Volume } \\
\text { (ml) }\end{array}$ & Total protein & $\begin{array}{l}\text { Protein conc. } \\
(\mathrm{mg} / \mathrm{ml})\end{array}$ & $\begin{array}{c}\text { Total Activity } \\
\text { (units) }\end{array}$ & $\begin{array}{l}\text { Yield } \\
(\%)\end{array}$ & $\begin{array}{c}\text { Specific activity } \\
\text { (unit/mg) }\end{array}$ & $\begin{array}{c}\text { Purification } \\
\text { (fold) }\end{array}$ \\
\hline Crude & 70 & $14.2 \mathrm{mg}$ & 0.202 & 113.6 & 100 & 8.0 & 1 \\
\hline 40-80\% dialyzed fraction & 15 & $1.48 \mathrm{mg}$ & 0.098 & 68.37 & 60.2 & 46.2 & 5.8 \\
\hline DEAE column E5 & 6 & $0.66 \mathrm{mg}$ & 0.11 & 44.9 & 39.5 & 68.1 & 8.5 \\
\hline
\end{tabular}

Unit $=$ release of reducing sugar in $\mu \mathrm{moles} / \mathrm{ml} / \mathrm{min}$. 


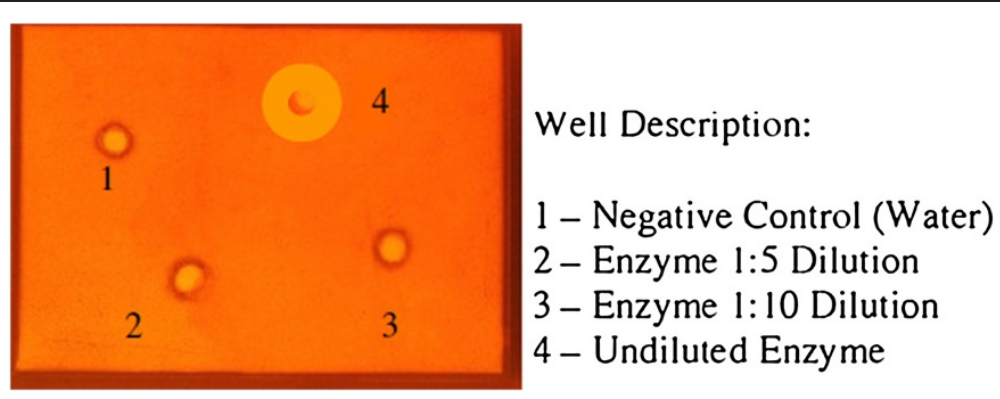

Figure 3 Congo red assay on agarose slab gel for elution fraction 5 (E5) shows endoglucanase (CMCase) activity.

Microbial Type Culture Collection Centre and Gene Bank with accession number MTCC 10046.

\section{DNA extraction and molecular phylogenetic analyses} using 16S rRNA gene sequence

Genomic DNA was extracted according to Marmur (Johnson 1994). PCR amplification of the 16S rRNA gene was carried out using universal primers 8-27f and 1492r and amplified PCR product was purified and sequenced as described by Saha and Chakrabarti (2006). A continuous stretch of 1514-nucleotide long gene sequences of $16 \mathrm{~S}$ rRNA gene was used to search for similar sequences from RDP database Release 10 http://rdp.cme.msu.edu/) using various online tools (CLASSIFIER, SEQMATCH). After confirmation of generic affiliation, sequences from type

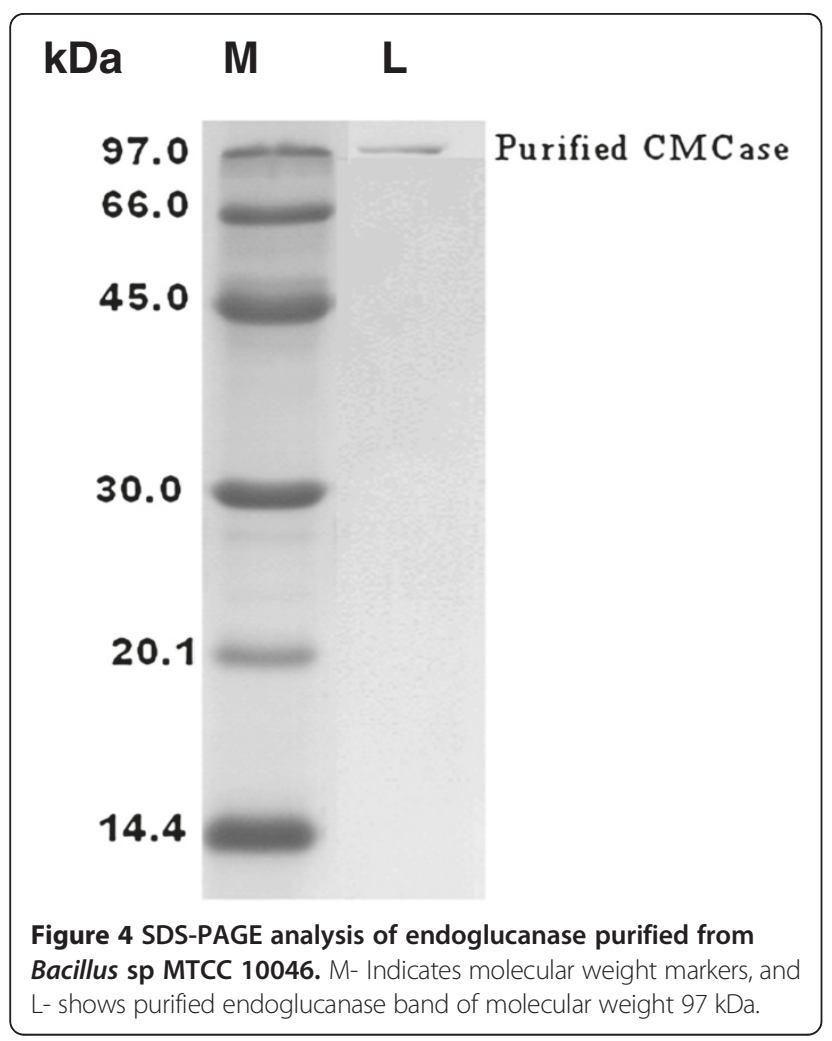

strains of different species were retrieved from GenBank. All these sequences were aligned by CLUSTAL_X programme (Thompson et al. 1997) and edited manually. Similarity values were determined after pair wise alignment by CLUSTAL_X programme followed by manual calculation. A phylogenetic tree showing relationship between $\mathrm{C} 1$ and other reference strains was constructed by neighbor-joining (NJ) method with Jukes and Cantor correction using TREECON software as described by Saha and Chakrabarti (2006).

\section{BIOLOG Method}

Suspension of active bacterial culture (Grown on TSA at $25 \mathrm{C}^{\circ}$ for 72 hours) of defined density (as per manufacture's instruction) was inoculated into microtitre plate. An inoculum of $150 \mu \mathrm{l}$ was dispensed into Biolog GN2 Microplates using a multichannel micropipette. The

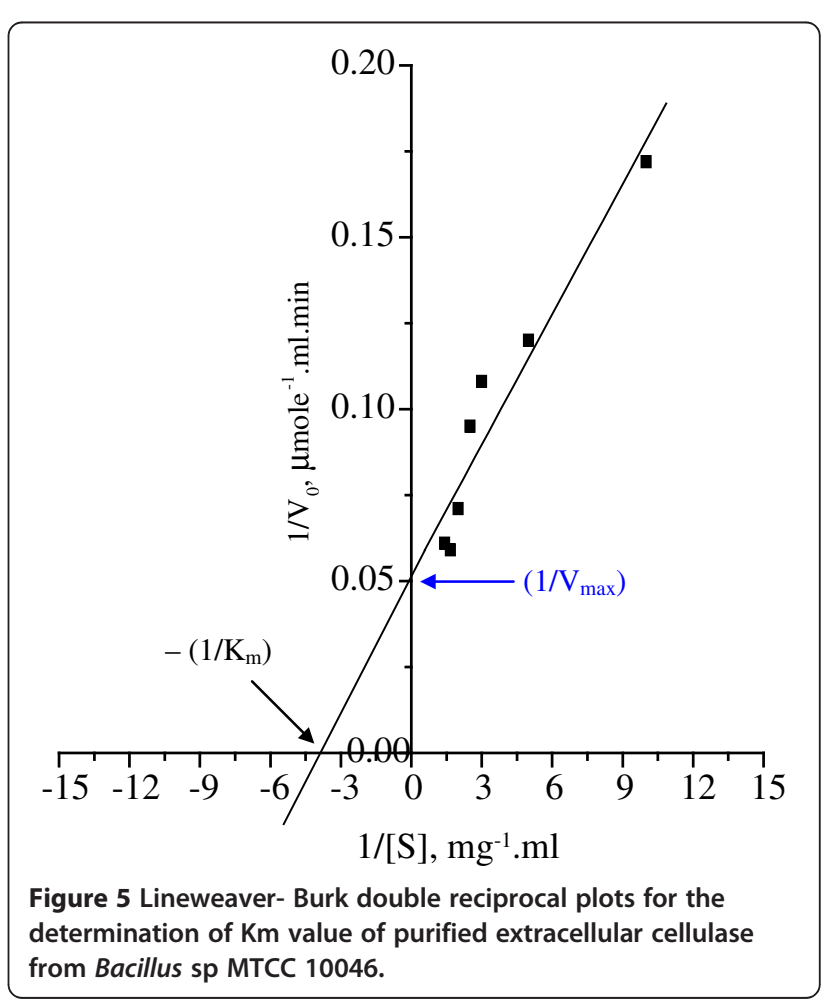




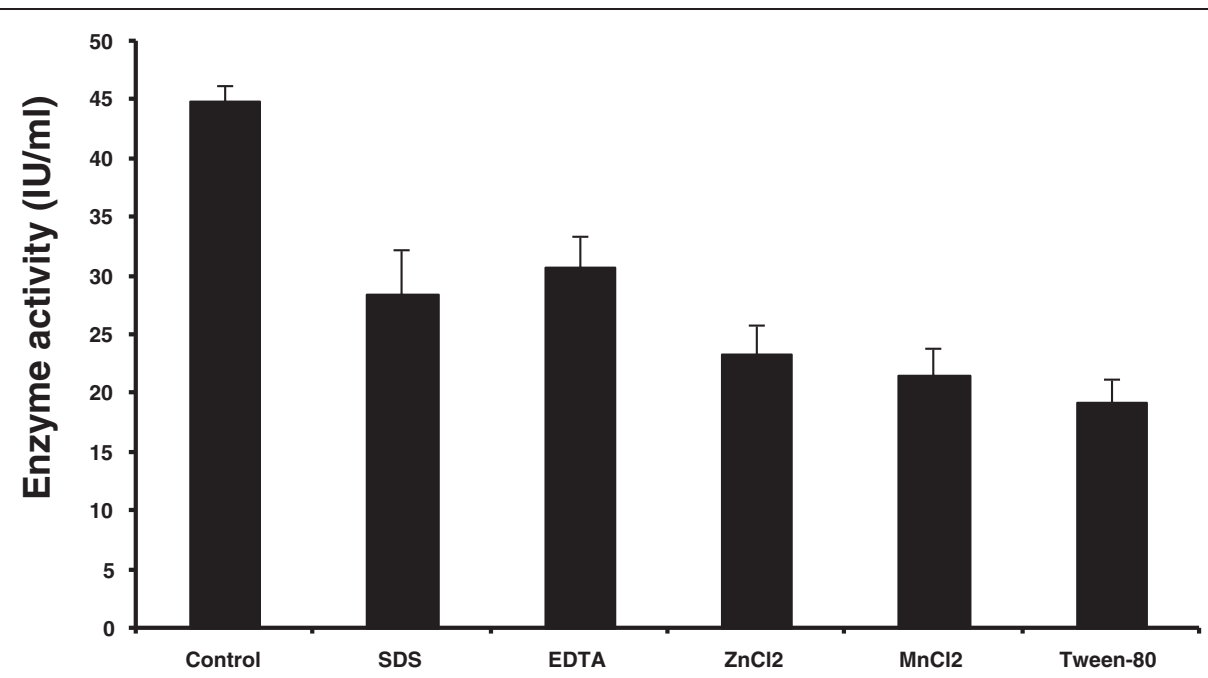

Figure 6 Effect of various chemicals on enzyme (endoglucanase) activity.

oxidation of various carbon sources as indicated by reduction of tetrazolium violet dye that results in production of purple color was monitored and recorded by using a micro plate reader that is coupled to a computer. The later has software for comparison of various patterns of oxidation as per Biolog database.

\section{Preparation of agricultural and paper waste used as} carbon source for CMCase production

The Banana agro waste (pseudo stem, leaves, etc.) used for saccharification were freshly collected. The waste was washed thoroughly with water and air dried. It was ground to powder using electric grinder and sieved. Orange fruit
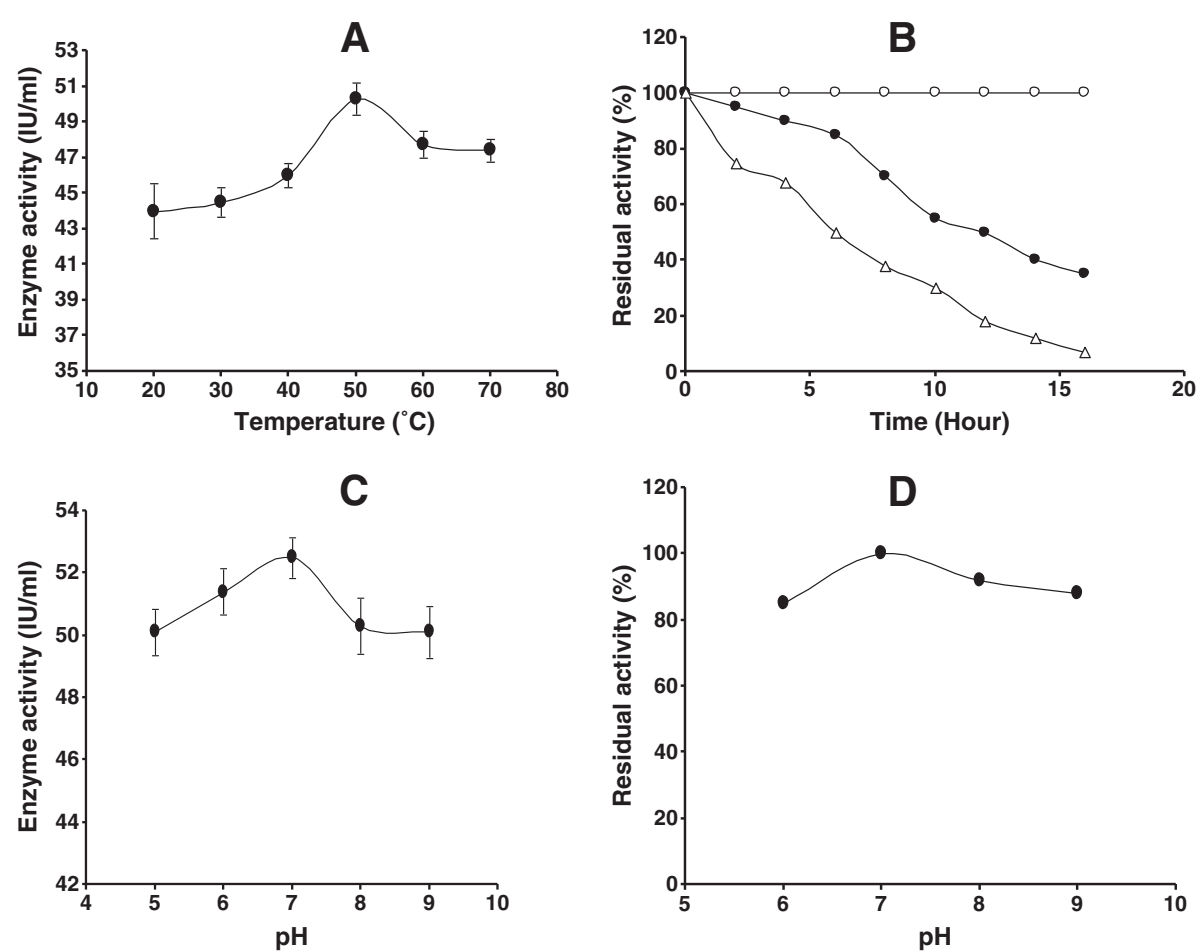

Figure 7 A Effect of temperature on endoglucanase activity. Symbol: closed circles, endoglucanase activity. B Thermal stability of endoglucanase: $5 \mathrm{IU}$ of endoglucanase were incubated in $0.02 \mathrm{M}$ acetate buffer $(\mathrm{pH} 7)$ at $50^{\circ} \mathrm{C}, 60^{\circ} \mathrm{C}$ and $70^{\circ} \mathrm{C}$ for different intervals and residual activity was determined. Symbol: endoglucanase activity at $50^{\circ} \mathrm{C}$ (open circle), endoglucanase activity $60^{\circ} \mathrm{C}$ (closed circle) and endoglucanase activity $70^{\circ} \mathrm{C}$ (open triangle). C Effect of $\mathrm{pH}$ on endoglucanase activity. Symbol: closed circles, endoglucanase activity. D The stability of endoglucanase in different $\mathrm{pH}$ at $50^{\circ} \mathrm{C}$. Symbol: closed circles, endoglucanase activity. 


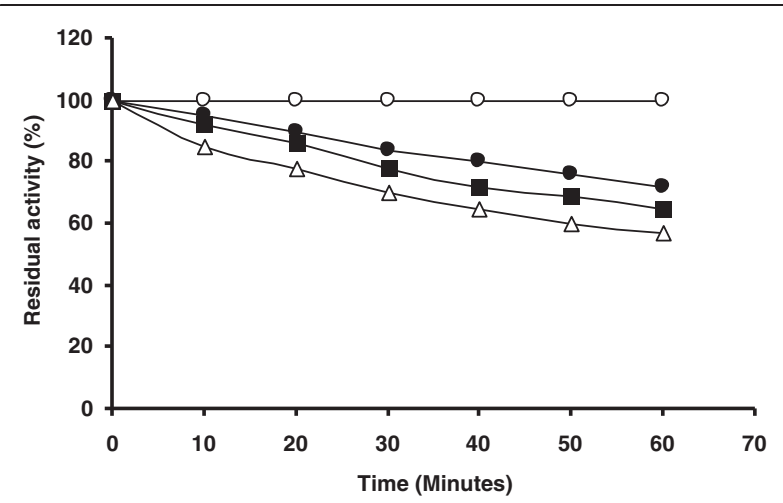

Figure 8 Stability of cellulase in various commercial detergents: endoglucanase was incubated at $50^{\circ} \mathrm{C}$ in the presence of various detergents and samples were removed every $10 \mathrm{~min}$ for $1 \mathrm{~h}$ and endoglucanase activity was determined: endoglucanase activity in control (without detergents) (open circle), endoglucanase activity in Ariel (closed circle), endoglucanase activity in Surf Excel (closed square) and endoglucanase activity in Tide (open triangle).

was washed thoroughly with water, peeled and sliced. The juice was removed with the aid of a squeezer and the pulp separated from the pericarp (albedo) and the three materials were sun-dried separately. They were later oven-dried at $70^{\circ} \mathrm{C}$, still being handle separately and then pounded using a mortar and pestle. All waste substrates then ground using a blender. Raw rice straw (RS) was obtained from local farmers. It was cut to $1-2 \mathrm{~cm}$ length and washed thoroughly with tap water until the washings were clean and colorless and then dried in a oven at $65^{\circ} \mathrm{C}$ to constant weight. Oven dried RS was then ground with electric grinder and was used in the experiments. Sugarcane baggasse also prepared in the same method. Papers were cut to $1 \times 6 \mathrm{~cm}$ length and were used in the experiment.

\section{Optimum concentration of CMC}

We find that among different carbon sources CMC was the best carbon source. So, to find out the suitable concentration of $\mathrm{CMC}$, different concentrations of CMC was tested.

\section{Enzyme separation}

The isolate $\mathrm{C} 1$ was inoculated in $100 \mathrm{ml}$ of Omeliansky medium (with $8 \% \mathrm{CMC}$ as carbon source) and was grown at $50^{\circ} \mathrm{C}$ for 7 days. Cell separation was made by centrifugation of fermented broth at $10,000 \times \mathrm{g}$ for $20 \mathrm{~min}$ and the cell free broth used as crude enzyme.

\section{Partial purification of endoglucanase}

Crude enzyme preparation was obtained after cultivation of the bacteria under submerged fermentation in shake flask condition. After centrifugation of the fermented broth the supernatant was subjected to ammonium sulphate precipitation with continuous stirring at $4^{\circ} \mathrm{C}$. The supernatant was precipitated with ammonium sulphate at $40-80 \%$ saturation for two hours with gentle stirring. The precipitated proteins were recovered by centrifugation at $8000 \mathrm{rpm}$ for $20 \mathrm{~min}$ and were dialyzed against $0.02 \mathrm{M}$ sodium acetate buffer ( $\mathrm{pH}$ 5.2) for $24 \mathrm{~h}$. The dialyzed solution was then applied to DEAE-Sepharose column.

\section{DEAE-Sepharose chromatography}

The semi-purified enzyme solution was subjected to DEAE-Sepharose column. The $35 \mathrm{ml}$ of the enzyme solution was applied to DEAE-Sepharose (Sigma-aldrich.) column which was previously equilibrated with $0.02 \mathrm{M}$ Acetate buffer ( $\mathrm{pH}$ 5.2). The entire purification was carried out at $4^{\circ} \mathrm{C}$. The column was first washed with equilibration buffer, and then bound proteins were eluted using linear gradient of $0.05-1.0 \mathrm{M} \mathrm{NaCl}$ (in acetate buffer) at a flow rate of $1 \mathrm{ml} /$ minute. The elute fractions $(3.0 \mathrm{ml})$ was by an automatic fraction collector and monitored for enzyme activity as well as for protein concentration at $280 \mathrm{~nm}$. After step-wise eluted each fraction from DEAE-Sepharose column, the total activity and specific activity of endoglucanase was assayed by DNS method, the fraction showing high activity were pooled and used for SDS-PAGE analysis.

\section{SDS-PAGE and determination of molecular weight of endoglucanase}

The active eluted fraction ( $E 5=5^{\text {th }}$ eluted fraction) collected from DEAE-Sepharose chromatography was used for analysis by SDS-PAGE (Robyt and White 1990). Resolving gel consisted of $12 \%$ polyacrylamide in Tris- $\mathrm{HCl}$ $(1.5 \mathrm{M}, \mathrm{pH}$ 8.8), while stacking gel consisted of $4.5 \%$ polyacrylamide in Tris- $\mathrm{HCl}(0.5 \mathrm{M}, \mathrm{pH} 6.8)$. Agarose slab gel method was used for congo red assay. An agarose slab gel $(0.5 \% \mathrm{~W} / \mathrm{V})$ was prepared containing $0.2 \%(\mathrm{~W} / \mathrm{V}) \mathrm{CMC}$ as substrate for the enzyme assay. Four slots were punched using a gel puncher and the different dilutions (1:5, 1:10 and undiluted) of fractions E5 and negative control were loaded in it. The slab was placed overnight in a moist chamber at room temperature for diffusion, followed by flooding with $0.5 \%$ aqueous congo red solution and de-staining of slab with $2 \mathrm{M} \mathrm{NaCl}$ solution and recorded as photo image for further confirmation.

\section{Determination of protein concentration}

Concentration of protein was determined following the method of Lowry et al. (1951) using BSA as standard and the protein in column elute fraction was also monitored by spectrophotometrically at $280 \mathrm{~nm}$.

\section{Assay of endoglucanase activity}

The activity of cellulase was assayed by incubating $1 \mathrm{ml}$ of reaction mixture consisting of $0.5 \mathrm{ml}$ of $1 \% \mathrm{CMC}$ in 
0.02 M Sodium acetate buffer, pH 5.2 and $0.5 \mathrm{ml}$ of suitably diluted enzyme solution incubated at $40^{\circ} \mathrm{C}$ for $1 \mathrm{hr}$. Enzyme and reagent blanks were incubated maintaining the same condition simultaneously. The amount of reducing sugar released was determined by dinitrosalicylic acid (DNS) method (Miller 1959). One International Unit (IU) of enzyme activity for endoglucanase was defined as the amount of enzyme releasing $1 \mu \mathrm{mol}$ of reducing sugar from $\mathrm{CMC}$ per minute. The specific activity determined as the number of units of enzyme activity per milligram of enzyme protein.

\section{Determination of $\mathrm{Km}$ value}

The Michaelis-Menten constant $(\mathrm{Km})$ of purified extracellular cellulase of strain $\mathrm{C} 1$ was determined by varying the concentration of $\mathrm{CMC}$ in $0.02 \mathrm{M}$ acetate buffer, $\mathrm{pH}$ 5.2. The kinetic parameters were determined from Lineweaver Burk double reciprocal plot (Lineweaver and Burk 1934). The initial velocity measured by quantitatively measuring the amount of one of the product at various time intervals (Robyt and White 1990).

\section{Effect of various chemicals on endoglucanase activity}

Enzyme activity measured in the presence of detergents (SDS, Tween-80), metal ions $\left(\mathrm{MnCl}_{2}, \mathrm{ZnCl}_{2}\right)$ and EDTA at a concentration of $10 \mathrm{mM}$.

\section{Effect of temperature on endoglucanase activity}

Enzyme activity was measured by treating the enzyme mixture at various temperatures, ranging from 20 to $70^{\circ} \mathrm{C}$.

\section{Effect of $\mathrm{pH}$ on endoglucanase activity}

The activity was measured at various $\mathrm{pH}$ (5.0-9.0), maintained using different buffering system.

\section{Effect of $\mathrm{pH}$ and temperature on stability of the enzyme}

The effect of $\mathrm{pH}$ on stability of the enzyme was determined by incubating $5 \mathrm{IU}$ of enzyme for $1 \mathrm{~h}$. at $50^{\circ} \mathrm{C}$, in a buffer of desired $\mathrm{pH}$ before addition to the reaction mixture; similarly the effect of temperature was determined by treating the enzyme at varying temperatures before addition to the reaction mixture.

\section{Stability of endoglucanase in commercial detergents}

The stability of endoglucanase in the presence of the commercial detergents such as Ariel, Surf Excel and Tide was investigated by incubating the enzyme in the presence of the detergent $(7 \mathrm{mg} / \mathrm{ml})$ at $50^{\circ} \mathrm{C}$. Aliquots of enzymes were removed at intervals of $10 \mathrm{~min}$. and the residual activity of the enzyme was determined using standard assay conditions.

\section{Statistical analysis}

All the data generated in the study are the mean \pm SEM of 3 replicates. All data were subjected to student's t- test analysis with significance level of $\mathrm{P}<0.01$ using SPSS software package.

\section{Competing interests}

The authors declare that they have no competing interests.

\section{Authors' contributions}

TKM and SKS have contributed to the experimental conception and design, to the acquisition of data, to the analysis and interpretation of data. They have also been involved in drafting and revising the manuscript. SS has performed most of the experiments including isolation of strain, screening of strain, purification and characterization of endoglucanase etc. SM has contributed to all related works for isolation of genomic DNA, amplify and sequence the $16 \mathrm{~S}$ rDNA. He also did the biolog experiment for characterization and identification of the strain. PS has contributed to the experiment related to the preparation of phylogenetic tree by using software. He also involved in drafting the manuscript and interpretation of phylogenetic tree. All authors read and approved the final manuscript.

\section{Acknowledgement}

Financial support for the first author provided by University Grant Commission through Burdwan University is gratefully acknowledged.

\section{Author details}

${ }^{1}$ Microbiology Laboratory, Department of Botany, Burdwan University, Burdwan 713104WB, India. ${ }^{2}$ Department of Microbiology, Burdwan University, Burdwan 713104WB, India. ${ }^{3}$ Department of Botany, Siksha Bhavana, VisvaBharati, Santiniketan 731235WB, India. ${ }^{4}$ Microbial type culture collection (MTCC), Institute of Microbial Technology (IMTECH), Sector 39-A, Chandigarh 160036, India.

Received: 17 October 2012 Accepted: 3 January 2013

Published: 12 January 2013

\section{References}

Acharya S, Chaudhury A (2011) Effect of nutritional and environmental factors on cellulase activity by thermophillic bacteria isolated from hot spring. I Sci Ind Res 70:142-148

Ashabil A, Lutfiye K, Burhan A (2011) Alkaline thermostable and halophilic endoglucanase from Bacillus licheniformis C108. Afr J Biotechnol 10:789-796

Bajaj BK, Pangotra H, Wani AM, Sharma P, Sharma A (2009) Partial purification and characterization of a highly thermostable and $\mathrm{pH}$ stable endoglucanase from a newly isolated Bacillus strain M-9. Indian J Chem Technol 16:382-387 Bakare MK, Adewale IO, Ajayi A, Shonukan OO (2005) Purufication and characterization of cellulase from the wild-type and two improved mutants of Pseudomonas fluorescens. Afri J Biotechnol 4:898-904

Bischoff KM, Rooney AP, Li XL, Liu S, Hughes SR (2006) Purification and characterization of a family 5 endoglucanase from a moderately thermophilic strain of Bacillus licheniformis. Biotechnol Lett 28:1761-1765

Costa RB, Silva MVA, Freitas FC, Leitao VSF, Lacerda PSB, Ferrara MA, Bon EPS (2008) Mercado e Perspectivas de Uso de Enzimas Industriais e Especiais no Brasil. In: Bon EPS, Ferrara MA, Corvo ML, Vermelho AB, Paiva CLA, Alencastro RB, Coelho RRR (eds) Enzimas em Biotecnologia, Producao, Aplicac oes e Mercados, 1st edn. Rio de Janeiro, Intercie^ncia, pp 463-488

Chen PJ, Wei TC, Chang YT, Lin LP (2004) Purification and characterization of carboxymethyl cellulase from Sinorhizobium fredii. Bot Bull Acad Sin 45:111-118

Ekperigin MM (2007) Preliminary studies of cellulase production by Acinetobacter anitratus and Branhamella sp. African J Biotechnol 6:28-33

George PS, Ahmad A, Rao MB (2001) Studies on carboxymethyl cellulase produced by an alkalothermophilic actinomycete. Bioresource Technol 77:171-175

Hahn-Hägerdal B, Galbe M, Gorwa-Grauslund MF, Lidén G, Zacchi G (2006) Bioethanol- the fuel of tomorrow from the residues of today. Trends Biotechnol 24:549-556

Johnson JL (1994) Similarity analysis of DNAs. In: Gerhard PE, Murray RG, Wood WA, Krieg NR (eds) Methods for General and Molecular 
Bacteriology, 1994th edn. American Society for Microbiology, Washington, DC, pp 656-682

Jukes TH, Cantor CR (1969) Evolution of protein molecules. In: Munro HN (ed) Mmmalian Protein Metabolism, 3rd edn. Academic Press, New York, pp 21-132

Kang HJ, Uegaki K, Fukada H, Ishikawa K (2007) Improvement of the enzymatic activity of the hyperthermophilic cellulase from Pyrococcus horikoshi. Extremophiles 11:251-256

Kaur J, Chadha BS, Kumar BA, Saini HS (2007) Purification and characterization of two endoglucanases from Melanocarpus sp. MTCC 3922. Bioresour Technol 98:74-81

Kim JY, Hur SH, Hong JH (2005) Purification and characterization of an alkaline cellulase from a newly isolated alkalophilic Bacillus sp. HSH-810. Biotechnol Lett 27:313-316

Lee YJ, Kim BK, Lee BH, Jo KI, Lee NK, Chung CH, Lee YC, Lee JW (2008) Purification and characterization of cellulase produced by Bacillus amyoliquefaciens DL-3 utilizing rice hull. Bioresource Technol 99:378-386

Liang L, Yesuf J, Schmitt S, Bender K, Bozzola J (2009) Study of cellulases from a newly isolated thermophilic and cellulolytic Brevibacillus sp. Strain JXL. J Ind Microbiol Biotechnol 36:961-970

Lineweaver H, Burk D (1934) The determination of enzyme dissociating constants. J Am Chem Soc USA 56:658-666

Lowry OH, Rosebrough NJ, Farr AL, Randall RJ (1951) Protein measurement with the folin phenol reagent. J Biol Chem 193:265-275

Mawadza C, Hatti-Kaul R, Zvauya R, Mattiasson B (2000) Purification and characterization of cellulases produced by two Bacillus strains. J Biotechnol 83(3):177-187

Miller GL (1959) Use of dinitrosalicylic acid reagent for determination of reducing sugars. J Analyt Chem 31:426-428

Miranda M, Kam TL, Wensheng Q (2009) The prospects of cellulase- producing bacteria for the bioconversion of lignocellulosic biomass. Int J Biol Sci 5:500-516

Omeliansky W (1902) Ueber die Garung der cellulose. Centrabl Bakt, II Abt 8:225-231

Robyt JF, White BJ (1990) Biochemical techniques: Theory and practical. Waveland Press, Inc Illinois, U.S.A

Saha P, Chakrabarti T (2006) Emticicia oligotrophica gen. nov., sp. nov., a new member of the family 'flexibacteraceae' Phylum Bacteroidetes. Int J Syst Evol Microbiol 56:991-995

Saratale DG, Oh SE (2011) Production of thermotolerant and alkalotolerant cellulolytic enzymes by isolated Nocardiopsis sp. KNU. Biodegradation 22:905-919

Shikata S, Saeki K, Okoshi H, Yoshimatsn T, Ozaki K, Kawai S, Ito S (1990) Alkaline cellulase for laundry detergents production by alkalophilic srains of Bacillus and some properties of crude enzyme. Agric Biol Chem 54:91-96

Singh J, Batra N, Sobti RC (2004) Purification and characterization of alkaline cellulose produced by a novel isolate, Bacillus sphaericus JS1. J Ind Microbiol Biotechnol 31:51-56

Sudan R, Bajaj BK (2007) Production and biochemical characterization of xylanase from an alkalitolerant novel sp Aspergillus niveus RS2. World J Microbiol Biotechnol 23:491-500

Teather RM, Wood PJ (1982) Use of Congo red-polysaccharide interactions in enumeration and characterization of cellulolytic bacteria from the bovine rumen. Appl Env Microbio 43:777-780

Thompson JD, Gibson TJ, Plewniak F, Jeanmougin F, Higgins DG (1997) The CLUSTAL_X windows interface: flexible strategies for multiple sequence alignment aided by quality analysis tools. Nucleic Acids Res 25(24):4876-4882

Tong CC, Cole AL, Shephard MG (1980) Purification and properties of the cellulases from the thermophilic fungus Thermoascus auriantiacus. Biochem J Gr Br 191:83-94

Van de Peer Y, Wachter RD (1997) Construction of evolutionary distance trees with TREECON for Windows: accounting for variation in nucleotide substitution rate among sites. Comput Appl Biosci 13:227-230
Viikari L, Alapuranen M, Puranen T, Vehmaanperä J, Siika-Aho M (2007) Thermo stable enzymes in lignocellulose hydrolysis. Adv Biochem Eng Biotechnol 108:121-145

Wood TM, Bhat KM (1988) Methods for measuring cellulase activities. Method Enzymol 160:87-112

Yin L, Huang PS, Lin HH (2010) Isolation of cellulase-producing bacteria and characterization of the cellulase from the isolated bacterium Cellulomonas Sp. YJ5. J Agric Food Chem 58:9833-9837

doi:10.1186/2193-1801-2-10

Cite this article as: Sadhu et al:: Production, purification and characterization of a novel thermotolerant endoglucanase (CMCase) from Bacillus strain isolated from cow dung. SpringerPlus 2013 2:10.

\section{Submit your manuscript to a SpringerOpen ${ }^{\odot}$ journal and benefit from:}

- Convenient online submission

- Rigorous peer review

- Immediate publication on acceptance

- Open access: articles freely available online

- High visibility within the field

- Retaining the copyright to your article

Submit your next manuscript at $\gg$ springeropen.com 